\title{
(อ) OPEN ACCESS \\ Hospital chaplains as ethical consultants in making difficult medical decisions
}

\author{
Waldemar Głusiec
}

Chair and Department of Humanities and Social Medicine, Medical University of Lublin, Lublin, Poland

\section{Correspondence to} Dr Waldemar Głusiec, Chair and Department of Humanities and Social Medicine, Medical University of Lublin, Lublin 20059, Poland;

waldemarglusiec@umlub.pl

Received 24 November 2020 Revised 21 January 2021 Accepted 27 January 2021

Check for updates

(c) Author(s) (or their employer(s)) 2021. Re-use permitted under CC BY-NC. No commercial re-use. See rights and permissions. Published by BMJ.

To cite: Głusiec W. $J$ Med Ethics Epub ahead of print: [please include Day Month Year]. doi:10.1136/ medethics-2020-107096
ABSTRACT

Background and aims Few Polish hospitals have Hospital Ethics Committee (HECs) and the services are not always adequate. In this situation, the role of HECs, in providing, among others, ethical advice on the discontinuation of persistent therapies, may be taken over by other entities. The aim of our research was to investigate, how often and on what issues hospital chaplains are asked for ethical advice in reaching difficult medical decisions.

Methods A survey of 100 Roman Catholic chaplains was conducted, that is, at least $10 \%$ of all chaplains currently working in Polish hospitals.

Results Of the participants, 29\% confirmed receiving requests for advice in making a morally difficult medical decision. Receiving this type of request was not conditional on the place of their service, duration of their pastoral mission or HEC membership. The largest group of chaplains $(21 \%)$ encounter questions concerning the ethical dilemmas associated with discontinuing persistent therapy. Patients and their families most often raise issues related to the methods of birth control, and the medical staff raise the issue of termination of pregnancy - as reported by $9 \%$ and $15 \%$ of chaplains, respectively. Most of the chaplains asked for help (79\%) experience a deficit of specialist knowledge in the area of medicine or ethics.

Conclusions In order to improve the quality of ethical consultations in Polish hospitals, in addition to further development of HECs, it is postulated to develop a system for bioethical education of chaplains.

According to the standards elaborated by the European Network of Health Care Chaplaincy ${ }^{1}$ patients in Polish hospitals, in addition to medical care, also have access to pastoral care. The option to resort to this type of care is guaranteed by Articles 36-38 of the Polish Patient Rights Act. ${ }^{2}$ According to 2011 data by Statistics Poland, ${ }^{3}$ the most numerous religious group in Poland are Roman Catholics (86.9\%), and the second largest community are followers of the Orthodox Catholic Church (1.31\%). The faithful of any of the remaining religions and religious communities do not exceed the $0.4 \%$ threshold. A natural consequence of this is the fact that in Poland the vast majority of hospital chaplains are Catholic clergy, with their number estimated at 700 priests. On the other hand, the guidelines by UNESCO ${ }^{4}$ and that of art. 19 of the Universal Declaration on Bioethics and Human Rights ${ }^{5}$ recommend that the Hospital Ethics Committees (HEC) operate within the national health service. Their primary task is to advise healthcare professionals, patients and families on ethical issues arising from clinical practice and patient care. ${ }^{6-8}$ Typical issues dealt with by HECs include decisions not to resuscitate, withdraw or abstain from life support procedures, the acceptability of informed refusal of consent to life-saving medical interventions. ${ }^{9}{ }^{10}$ Research conducted by Czarkowski et al proves that only a few Polish hospitals have HECs, and the structure, services and workload are not always adequate. ${ }^{11}$ Confronted with this situation, healthcare professionals, patients and their families, who deal with moral dilemmas, are often forced to seek advice elsewhere, perhaps from people they perceive as moral authorities, and whom they trust. For many of them, the hospital chaplain demonstrates both of the aforesaid qualities.

Subject literature includes various reports of crucial role of hospital chaplains in supporting families during decisions about 'not for resuscitation' and in supporting families during and after resuscitation procedures. ${ }^{12}$ There were also theoretical deliberations on <chaplains' roles as mediators in critical clinical decisions ${ }^{13}$ and pilot research on using chaplains to facilitate advance care planning in medical practice. ${ }^{14}$ The issue of ethical advice provided by hospital chaplains to patients, their families and medical staff in the context of the need to make a difficult medical decision still remains a poorly researched subject. What was researched so far, were only the views of Australian healthcare chaplains concerning their role and involvement in patient/family healthcare treatment decision ${ }^{15}$ and the phenomenon of inclusion of chaplains working in the USA into healthcare team discussions regarding medical decisions. ${ }^{16}$

The objective of our study was to analyse the phenomenon of resorting to hospital chaplains for advice, when making a morally difficult medical decision. The question was to verify if, who, how often and on what bioethical issues, ask for an opinion from a Catholic chaplain working in a Polish hospital? We also wanted to collect declarations of chaplains about their ways of dealing with questions that border ethics and medicine. The author presents two research hypotheses. First of all, some of the demand for ethical counselling that is barely implement by HECs in Poland is satisfied by hospital chaplains. Second, the issue of discontinuation of persistent therapy, typical of the work of HECs, often appears in ethical and medical questions addressed to hospital chaplains.

\section{MATERIAL AND METHODS}

For the purposes of the study, we elaborated an original questionnaire, which was later refined through three interviews with hospital chaplains and two consultations with a group of 10 experts in 
the field of medical ethics, bioethics and medical sociology. The link to the questionnaire developed in electronic form was sent to chaplains through all 44 diocesan curias of the Roman Catholic Church in Poland and the National Healthcare Ministry. This enabled us to reach with the information about the survey to all Catholic hospital chaplains nationwide.

The questionnaire contained 15 closed and semiopen questions. The first concerned the current place of service of the chaplain, seniority in care and treatment centres and the group of people who were asking them for ethical advice, when making a difficult medical decision. The subsequent series of questions concerned the frequency of requests for opinion on specific bioethical issues. First we asked about the questions that are particularly discussed in the Catholic ethics. The ultimate three questions concerned the possible doubts of hospital chaplains in formulating their opinions and ways for acquiring additional information on ethical and medical issues.

The survey was conducted in the period from 1 March to 31 May 2020. A total of 111 respondents sent back the completed questionnaire. The demographics made it possible to select a group of 100 chaplains currently working in hospitals. The remaining respondents declared work in other types of care and treatment institutions. The analysis of the gathered material was carried out using the STATA V.12 (academic license for the Medical University of Lublin).

\section{RESULTS}

Twenty-four per cent of the 100 hospital chaplains simultaneously served in other care and treatment facilities, such as hospices, psychiatric hospitals, care and treatment facilities and nursing homes. All respondents completed theological studies as part of their formation and were ordained to the office of presbyterate, which is the second of the three degrees of ordination in the Roman Catholic Church. The majority of chaplains worked in small town hospitals: $6 \%$-in a town with less than 5000 inhabitants, 45\%—in those with 5 -50 000 inhabitants, 26\% - in cities with 50-200 000 residents; and 23\%-in a city with over 200000 residents. The length of service in care and treatment facilities of the surveyed chaplains ranged from 0.5 to 36 years (with a mean of 10 years). Most of the respondents declared that their experience was less than 10 years: $35 \%-0.5-5$ years, 28\%-6-10 years, 19\%-11-15 years, 10\%-16-20 years, 8\%-21 years and more. About one-third (27\%) of the respondents declared membership in HECs.

\section{Requests for advice in making a difficult medical decision}

About one-third of the surveyed chaplains (29\%) confirmed that they were asked for help in making a difficult decision regarding the issue of contraception, In Vitro Fertilisation (IVF), prenatal testing, termination of pregnancy, discontinuance of persistent therapy or other medical procedure. There were no significant differences in relation to the size of town/city, where the hospital was located $\left(\chi^{2}=4.95, \mathrm{df}=3, \mathrm{p}=0.18\right)$ (table 1 ) or the length of service in care and treatment centres $(Z=1.01, p=0.314)$ (table 1). Majority of the chaplains, who were asked for ethical advice did not work in HECs (only $\mathrm{N}=12,41.33 \%$ declared that they are members of HECs) (table 1).

Requests for advice in making a difficult medical decision are directed to chaplains both by patients and/or their families (as indicated by $27 \%$ of the respondents) and by doctors and/or other medical personnel (as indicated by 19\% of the respondents). Patients (19\%) do ask for such advice exactly as often as their relatives (19\%). Doctors (16\%) are most frequently turning for chaplains' advice, followed by nurses (11\%), and less often (4\%) by midwives and paramedics (2\%) (figure 1).

Patients, their families and medical staff turn to hospital chaplains for advice on a wide range of bioethical issues. The largest number of respondents indicated that these questions concerned the problem of discontinuing persistent therapy (21\%) and methods for regulating conceptions such as hormonal contraception, surgical sterilisation, postcoital contraceptives and intrauterine devices (19\%). The remaining questions concerned artificial insemination, for example, IVF procedures (17\%), termination of pregnancy (17\%), prenatal tests $(14 \%)$, organ donation for transplant (18\%), declaring patient's death (11\%), reanimation and resuscitation (10\%), infectious diseases (9\%), vaccinations (9\%), drugs with significant side effects such as opioids $(6 \%)$, palliative sedation and coma (3\%), sex reassignment $(3 \%)$. None of the respondents reported receiving a request for an opinion on plastic and aesthetic surgery procedures. Among the other issues (that were not included in the questionnaire), one chaplain added the issue of continuing

\begin{tabular}{|c|c|c|c|c|c|c|c|c|}
\hline \multicolumn{9}{|c|}{$\begin{array}{l}\text { Was the chaplain ever asked to make a difficult decision concerning contraception, IVF, prenatal tests, termination of pregnancy, discontinuance of persistent therapy or other } \\
\text { medical procedure? }\end{array}$} \\
\hline \multicolumn{9}{|c|}{ Size of the town/city where the hospital is located Independence test $\chi^{2}=4.95, \mathrm{df}=3, p=0.18$} \\
\hline & \multicolumn{3}{|l|}{ Yes } & \multicolumn{3}{|l|}{ No } & \multicolumn{2}{|l|}{ Total } \\
\hline$<5000$ residents & \multicolumn{3}{|l|}{1} & \multicolumn{3}{|l|}{5} & \multicolumn{2}{|l|}{6} \\
\hline 5-50 000 residents & \multicolumn{3}{|l|}{9} & \multicolumn{3}{|l|}{36} & \multicolumn{2}{|l|}{45} \\
\hline 50-200 000 residents & \multicolumn{3}{|l|}{9} & \multicolumn{3}{|l|}{17} & \multicolumn{2}{|l|}{26} \\
\hline$>200000$ residents & \multicolumn{3}{|l|}{10} & \multicolumn{3}{|l|}{13} & \multicolumn{2}{|l|}{23} \\
\hline Total & \multicolumn{3}{|l|}{29} & \multicolumn{3}{|l|}{71} & \multicolumn{2}{|l|}{100} \\
\hline \multirow[t]{5}{*}{ Seniority in care and treatment institutions } & $\mathrm{N}=100$ & & & \multirow{3}{*}{\multicolumn{3}{|c|}{$\begin{array}{l}\text { No } \\
\mathrm{N}=71\end{array}$}} & \multirow{3}{*}{\multicolumn{2}{|c|}{$\begin{array}{l}\text { Mann } \\
\text { Whitney U-test }\end{array}$}} \\
\hline & \multirow{2}{*}{\multicolumn{3}{|c|}{$\begin{array}{l}\text { Yes } \\
\mathrm{N}=29\end{array}$}} & & & & & \\
\hline & & & & & & & & \\
\hline & M & \pm SD & M & $\pm \mathrm{SD}$ & M & $\pm \mathrm{SD}$ & Z & $p$ \\
\hline & 10.86 & 6.79 & 10.0 & 9.77 & 7.33 & 7.5 & 1.01 & 0.314 \\
\hline \multirow{2}{*}{$\begin{array}{l}\text { Work at Hospital Ethics } \\
\text { Committees }\end{array}$} & Yes & & & \multicolumn{3}{|l|}{ No } & \multicolumn{2}{|l|}{ Total } \\
\hline & \multicolumn{3}{|l|}{12} & \multicolumn{3}{|l|}{15} & \multicolumn{2}{|l|}{27} \\
\hline
\end{tabular}




\section{People asking for advice}

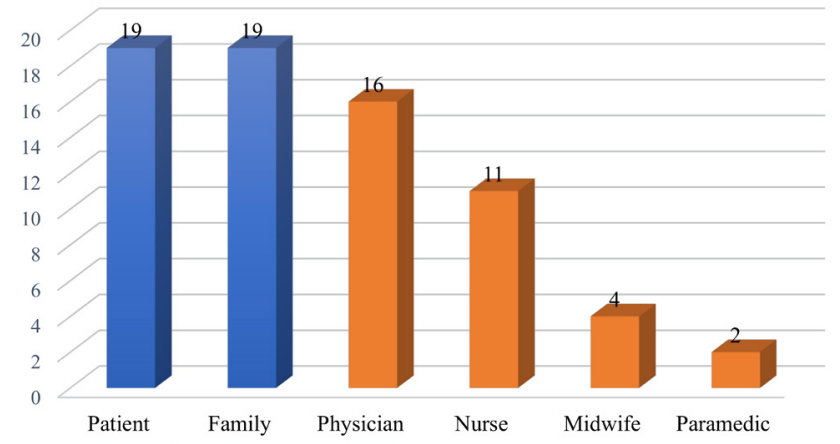

Figure 1 Categories of people who turn to chaplains for ethical advice in making difficult medical decision.

cancer treatment and another-limb amputation. Within the above categories, the questions most often asked of hospital chaplains concerned methods of birth control, discontinuance of persistent therapy and donating organs for transplantationwith $9 \%, 8 \%$ and $8 \%$ of chaplains, respectively, admitting that they encountered such questions several times a year (figure 2).

Majority of the 29 hospital chaplains, who were asked for advice in making difficult ethical and medical decisions admit that they lacked expertise in certain bioethical issues. When asked whether it happened that the chaplain had to look for additional information after being asked a question, 23 (79.31\%) of the respondents replied confirming it. Asked how to deal with resolving doubts, the chaplains most often answered 'I was looking for a solution to a problematic issue in the scientific literature'-16 such answers (69.56\%). The other ways of dealing with lack of medical and or ethical information by hospital chaplains included: talking about the problematic issue with a specialist in moral theology, ethics or bioethics-11 (47.82\%), talking with another chaplain-11 (47.82\%), asking members of medical staff-10 (43.47\%), looking for a solution to a problematic issue on the internet-5 (21.73\%). One of the interviewed chaplains (4.34\%) mentioned documents of the Church's Magisterium as an additional source of information.

\section{DISCUSSION}

In discussing the results of the present research we should note that it proves difficult to precisely define the number of hospital chaplains serving in Poland. Statistics Poland reports that in there were 949

\section{Thematic areas of advice}

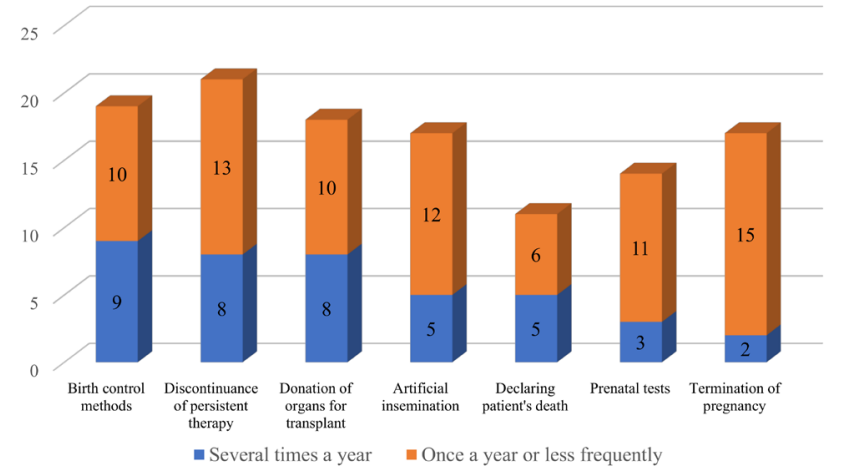

Figure 2 Thematic scope of ethical questions that the chaplains were asked by patients, families or medical staff. general hospitals operating nationwide in $2018 .{ }^{17}$ In each of these institutions, patients had access to pastoral service. The largest hospitals employ two or more chaplains, while in smaller ones chaplains are employed on part-time contracts. Some of the chaplains work simultaneously in several institutions. Due to the lack of complete statistics of chaplains employed by the health and social care sector, both in the relevant state and church institutions, the opinion of the National Pastoral Care of Healthcare remains binding. ${ }^{18}$ According to this opinion, the total number of pastors actively working on the basis of employment contracts or as volunteers is 900-1000, including some 700 hospital chaplains. ${ }^{19}$ Taking these estimated data into account, it should be stated that no less than $10 \%$ of Roman Catholic hospital chaplains from all over Poland took part in our survey.

Research by Carey and Cohen, conducted in an Australian clinical context, ${ }^{15}$ demonstrated that most chaplains consider that helping patients and their families make treatment decisions as constituting part of their pastoral ministry. Nevertheless, they noted differences in involvement of volunteer and staff chaplains, Catholic and Protestant, male and female chaplains. Diversity in terms of religion and gender of hospital chaplains is also evident in the American research. ${ }^{16}$ On this background, the group of Polish hospital chaplains proves exceptionally homogeneous. It is made up almost entirely by Roman Catholic clergy, that is, men who were ordained to the presbyterate. In several hospitals, in addition to Catholic chaplains, the pastoral ministry is also performed by a few Orthodox clergy and Protestant pastors. Of course, in every hospital, patients of particular Christian denominations and other religions can benefit from the ministry of their own clergy, called on request. This state of affairs results from the religious structure of Polish society, in which, according to Statistics Poland from 2011, Roman Catholics constitute $86.9 \%$. $^{3}$ This is also an explanation of why only Roman Catholic chaplains were surveyed. Half of the survey participants $(51 \%)$ work in hospitals located in towns up to 50000 residents. This allows us to assume that they perform pastoral service in small institutions-mainly municipal and poviat hospitals, providing first reference level of healthcare services. ${ }^{20}$ We may also assume that, in this type of hospitals, there are much fewer situations rendering it necessary to make a difficult medical, ethically complicated decisions than in hospitals providing services at the second and third reference levels, which are located mainly in large cities. However, the analysis of the number of requests for advice directed to chaplains, taking into account the size of the town in which they work, failed to reveal statistically significant differences here. This may indicate that it is not the type of institution, where the chaplain serves, but rather his personality and personal commitment to the pastoral service that influence the fact of addressing requests on advice in ethicalmedical questions to them. Confirmation of this thesis requires further research. However, an additional argument for its correctness is supplied by the second analysis, that is, the lack of correlation between the number of requests for advice to chaplains and length of their service in care and treatment facilities.

The fact that almost one-third (29\% of respondents) of hospital chaplains in Poland were asked for ethical advice when making a difficult medical decision not only by patients and their families, but also by medical personnel, and also the results of research by Czarkowski et al, ${ }^{11}$ proving that only few Polish hospitals have HECs and the services are not always adequate, further confirms the first research hypothesis. Some of the demand for ethical counselling, hardly met by HECs in Polish conditions, is satisfied by Roman Catholic hospital chaplains. The question of what extent is the phenomenon of replacing HEC advice with chaplain advice requires further research among patients, families and medical staff. There are many indications that it is greater in Poland than in the West. A 
study published in 2015 demonstrated that there are very few, that is, only 110 Ethical Teams operating in Polish hospitals. There are also doubts as to whether all these Ethics Teams can be considered equivalents of the HECs operating in the West. Most of the Ethical Teams operating in Poland lack professionals in ethics, clergy, lawyers or psychologists, and the vast majority of their members are doctors. It is inconsistent with the applicable standards, as it limits the possibility of a multilateral and comprehensive analysis of issues from the perspective of medical science, applicable law and ethical standards. ${ }^{21}$ In addition, as much as $88 \%$ of issues that Polish Ethics Teams deal with relate to unethical behaviour and conflicts between hospital staff or hospital staff and patients and their families. These issues are not directly related to reaching difficult medical decisions. ${ }^{9}$ The results of the conducted research also confirm the second research hypothesis. The issue of discontinuance of persistent therapy, ${ }^{910}$ which is typical of the work of HECs, is the subject of questions addressed to the widest group of Polish hospital chaplains (21\%). This means that hospital chaplains are partially filling the gap left by Polish HECs in supporting patients, their families and medical staff in deciding not to resuscitate, withdraw or discontinue using life support procedures or refuse the consent to life-saving medical measures. In addition, chaplains are asked questions on a wide range of bioethical issues, including those that are not part of the typical work area of HECs. Often these are questions concerning the morality of methods of regulating conception such as hormonal contraception, surgical sterilisation, postcoital contraceptices and Intra Uterine Devices (IUDs). There are also numerous questions about artificial insemination, for example, the IVF procedure. This may mean that there is room for both HECs and individual chaplains in the social demand for ethical counselling.

Some hospital chaplains provide medical and ethical counselling in two different paths. In addition to individual interviews with patients, families and healthcare professionals, they have the opportunity to express their views through the HECs of which they are members. The survey we have conducted does not allow for verification of proportion of opinions submitted by the respective chaplains in the framework of these two activities. Nevertheless it still demonstrates that in certain bioethical issues, almost $80 \%$ of chaplains experience a deficit of expertise in the field of medicine or ethics. What must be deemed a positive signs is that the majority of them search for information in scientific literature, and every second consults a specialist in moral theology, ethics, bioethics or another chaplain. These results confirm the validity of the two postulates that appear in subject literature. The first is the demand for permanent formation of hospital chaplains in the field of, inter alia, medical introductory studies, pastoral psychology and medical law. ${ }^{22} 23$ The second postulate is the constant formation of members of HECs in the field of bioethics. ${ }^{24}$

The basic limitation of the present study is that it covered only Roman Catholic clergy. The study ignored the negligible percentage of Orthodox and Protestant clergy, who are employed as hospital chaplains. Due to the religious structure of Polish society, representatives of religions other than Christianity do not formally hold this type of positions. Two important factors also had an impact on the percentage of survey participants. First, the link to the questionnaire was provided to the chaplains through several tens of institutions, such as diocesan curias and the National Healthcare Ministry. The participation of intermediaries does not ensure that the information concerning the survey reached all Roman Catholic hospital chaplains in Poland. Second, the questionnaire was elaborated in electronic form only, and this may formed a barrier for a certain group of chaplains, who are not very familiar with digital technology.

\section{CONCLUSIONS}

In Poland, some of the demand for ethical counselling, hardly met by HECs, is satisfied by Roman Catholic hospital chaplains. Every third chaplain is asked for advice, when making a morally difficult medical decision. Receiving such a request is not conditional on the place of their service, duration of their pastoral mission or HEC membership. The widest group of chaplains encountered questions regarding the moral assessment of discontinuation of persistent therapy. Patients and their families most often turn to chaplains asking about methods of birth control, while the medical staff asks about the dilemmas related to termination of pregnancy. Most of the chaplains asked for help experience a deficit of specialist knowledge in the field of medicine and/or ethics. In order to improve the quality of ethical consultations in Polish hospitals, in addition to further development of HECs, it is postulated to develop a system for bioethical education of chaplains.

Contributors WG contributed to the planning, management and reporting of the work described in the article. WG is responsible for all content.

Funding This study was supported by Uniwersytet Medyczny w Lublinie (DS 507 (J. Sak)).

\section{Competing interests None declared.}

Patient consent for publication Not required.

Provenance and peer review Not commissioned; externally peer reviewed. Data availability statement Data are available upon request.

Open access This is an open access article distributed in accordance with the Creative Commons Attribution Non Commercial (CC BY-NC 4.0) license, which permits others to distribute, remix, adapt, build upon this work non-commercially, and license their derivative works on different terms, provided the original work is properly cited, appropriate credit is given, any changes made indicated, and the use is non-commercial. See: http://creativecommons.org/licenses/by-nc/4.0/.

\section{ORCID iD}

Waldemar Głusiec http://orcid.org/0000-0002-7831-6895

\section{REFERENCES}

1 European Network of Health Care Chaplaincy. Standards for health care chaplaincy in Europe, Turku, 2002. Available: http://enhcc.eu/turku_standards.htm [Accessed 5 Nov 2020]

2 . Act of November 6, 2008 on patient's rights and the Patient's Rights Ombudsman (Journal of Laws of 2009, No. 52, item 417).

3 Główny Urząd Statystyczny. Wyznania religijne: stowarzyszenia narodowościowe i etniczne w Polsce 2009-2001. Warszawa Departament Badań Społecznych i Warunków Życia; 2013: 9-184

4 UNESCO. Guide N.1 establishing bioethics committees, Paris, 2005. Available: http:// www.unesco-chair-bioethics.org/?mbt_book=guide-no-1-establishing-bioethicscommittees [Accessed 5 Nov 2020].

5 UNESCO. Universal declaration on bioethics and human rights, Paris, 2006. Available: https://en.unesco.org/themes/ethics-science-and-technology/bioethics-and-humanrights [Accessed 5 Nov 2020].

6 Florida Bioethics Network. Guidelines for ethics committees. Miami: Florida bioethics network, 2011. Available: https://fbn.miami.edu [Accessed 5 Nov 2020].

7 Slowther A, Johnston C, Goodall J, et al. A practical guide for clinical ethics support. Ethox Centre: Oxford, 2004.

8 Slowther A, Johnston C, Goodall J, et al. Development of clinical ethics committees. BMJ 2004;328(7445):950-2.

9 Annas G, Grodin M. Hospital ethics committees, consultants, and courts. AMA J Ethics 2016;18(5):554-9.

10 Czarkowski M. Kliniczne konsultacje etyczne w Polsce: potrzeby i ograniczenia. Med Prakt 2017;11:24-129.

11 Czarkowski M, Kaczmarczyk K, Szymańska B. Hospital ethics committees in Poland. Sci Eng Ethics 2015;21(6):1525-35.

12 Timmins F, Pujol N. The role of healthcare chaplains in resuscitation: a rapid literature review. J Relig Health 2018:57(3):1183-95.

13 Harris S. Chaplains' roles as mediators in critical clinical decisions. AMA J Ethics 2018;20(7):E670-4.

14 Lee AC, McGinness CE, Levine S, et al. Using chaplains to facilitate advance care planning in medical practice. JAMA Intern Med 2018;178(5):708-10.

15 Carey LB, Cohen J. Religion, spirituality and health care treatment decisions: the role of chaplains in the Australian clinical context. J Health Care Chaplain 2008; 15(1):25-39.

16 Jeanne Wirpsa M, Emily Johnson R, Bieler J, et al. Interprofessional models for shared decision making: the role of the health care chaplain. $J$ Health Care Chaplain 2019;25(1):20-44. 
17 Statistics Poland. Available: https://stat.gov.pl/en/basic-data/ [Accessed 5 Nov 2020].

18 Krajowe Duszpasterstwo Służby Zdrowia. Available: https://kdsz.pl [Accessed 5 Nov 2020].

19 Bereszczyński M. Kapelani obciążają szpitale, ale są potrzebni pacjentom. Dz Łódz.

20 . Regulation of the Minister of health and social welfare of 22 December 1998 on the National Hospital network and their reference levels (Journal of laws 1998.164.1193).

21 American Academy of Pediatrics. Committee on Bioethics. Institutional ethics committees. Committee on bioethics. Pediatrics 2001;107(1):205-9.
22 Krobicki M. Przygotowanie Kapelana szpitalnego do współpracy z zespołem medycznym w opiece nad chorym. SEeB 2009;7(1):265-7.

23 Binnebesel J, Krakowiak P, Krobicki M. Ku Szkole Opieki Duszpasterskiej św. Jana Bożego. In: Muszala A, Binnebesel J, Krakowiak P, eds. Dolentium hominum: duchowni i świeccy wobec ludzkiego cierpienia. Kraków: Prowincja Polska Zakonu Szpitalnego św. Jana Bożego, 2011: 28-54.

24 Czarkowski M. Jak zakładać szpitalne komisje etyczne. Pol Merk Lek 2010;165:207-10. 